Anna Brzęk

Anna Famuła ${ }^{1}$

Anna Kowalczyk ${ }^{2}$

Ryszard Plinta ${ }^{3}$

\title{
EFFICIENCY OF LUNG VENTILATION FOR PEOPLE PERFORMING WIND INSTRUMENTS
}

\author{
STAN FUNKCJONALNY UKŁADU ODDECHOWEGO \\ U MUZYKÓW GRAJĄCYCH NA INSTRUMENTACH DĘTYCH
}

Medical University of Silesia / Śląski Uniwersytet Medyczny w Katowicach, Katowice, Poland

School of Health Sciences / Wydział Nauk o Zdrowiu

${ }^{1}$ Department of Kinesiology, Chair of Physiotherapy / Zakład Kinezjologii, Katedra Fizjoterapii

${ }^{2}$ Department of Physiotherapy, Chair of Physiotherapy / Zakład Fizjoterapii, Katedra Fizjoterapii

${ }^{3}$ Department of Adapted Physical Activity and Sport, Chair of Physiotherapy / Zakład Adaptowanej Aktywności Fizycznej i Sportu,

Katedra Fizjoterapii

\begin{abstract}
Background: Wind instruments musicians are particularly prone to excessive respiratory efforts. Prolonged wind instruments performing may lead to changes in respiratory tracts and thus to respiratory muscles overload. It may result in decreasing lung tissue pliability and, as a consequence, in emphysema. Aim of the research has been to describe basic spirometric parameters for wind players and causes of potential changes. Material and Methods: Slow and forced spirometry with the use of Micro Lab Viasys (Micro Medical, Great Britain) was conducted on 31 wind musicians (group A). A survey concerning playing time and frequency, weight of instruments, and education on diaphragmatic breathing was conducted. The control group included 34 healthy persons at similar age (group B). The results were statistically described using Excel and Statistica programmes. Results: The respiratory parameters were within the range of physiological norms and forced expiratory volume in $1 \mathrm{~s}$ to forced vital capacity $\left(\mathrm{FEV} / \mathrm{FVC}_{1}\right)$ exceeded in both groups the values of $100 \%$. Forced vital capacity and expiratory vital capacity (EVC) values were significantly lower in the group of musicians than in the control group ( $\mathrm{p}<0.001)$. In $45 \%$ the group A used diaphragmatic breathing, in $31 \%$ of examinees mixed respiratory tract was observed. The significant discrepancy of individual parameters was obtained regarding age and the length of time when performing wind instrument. Conclusions: Spirometric parameters relative to standards may prove a good respiratory capacity. Peak expiratory flow (PEF) and FEV may indicate that a proper technique of respiration during performance was acquired. The length of time when performing wind instrument may influence parameters of dynamic spirometry. Med Pr 2016;67(4):427-433
\end{abstract}

Key words: risk assessment, forced spirometry, disturbances of ventilation, wind instrument, dynamic spirometry, medical consequence

\begin{abstract}
STRESZCZENIE
Wstęp: Muzycy grający na instrumentach dętych są szczególnie narażeni na nadmierny wysiłek głosowy i w konsekwencji na przeciążenie mięśni oddechowych. Długotrwała gra na instrumencie dętym może prowadzić do zmian w układzie oddechowym, m.in. do zmniejszenia elastyczności tkanki płuc, co może powodować rozedmę. Celem pracy była ocena parametrów spirometrycznych i ich ewentualnych zmian u muzyków grających na instrumentach dętych. Materiał i metody: Badania przeprowadzono z użyciem spirometru Micro Lab Viasys (prod. Mikro Medical, Wielka Brytania) wśród 31 muzyków grających na instrumentach dętych (grupa A). Badanym dodatkowo zadano pytania dotyczące stażu i częstości gry, wagi instrumentu i edukacji na temat oddychania przeponowego. Grupę porównawczą stanowiły 34 zdrowe osoby w podobnym przedziale wiekowym (grupa B). Wyniki poddano analizie statystycznej z wykorzystaniem programów Excel i Statistica. Wyniki: Parametry oddechowe mieściły się w normach fizjologicznych, a wskaźniki natężonej objętości wydechowej pierwszosekundowej do natężonej pojemności życiowej (forced expiratory volume in $1 \mathrm{~s}$ to forced vital capacity - FEV/FVC) osiągnęły wartości powyżej 100\% w obu badanych grupach. Natomiast wartości wskaźników FVC i wydechowej pojemności życiowej (expiratory vital capacity - EVC) były znacznie niższe w grupie artystów niż w grupie porównawczej $(\mathrm{p}<0,001)$. W grupie A torem przeponowym oddychało $45 \%$ badanych, natomiast mieszany tor oddechowy zaobserwowano u 31\%. Znaczna dysproporcja wartości poszczególnych parametrów występowała w przypadku wieku i liczby godzin gry na instrumentach dętych. Wnioski: Badane parametry spirometryczne wskazują na dobry stan funkcjonalny układu oddechowego u muzyków grających na instrumentach dętych. Wskaźniki FEV i szczytowy przepływ wydechowy (peak expiratory flow - PEF) sugerują, że muzycy przeanalizowali i opanowali właściwe techniki oddychania podczas gry. Liczba godzin gry na instrumentach dętych może wpływać na parametry spirometrii dynamicznej. Med. Pr. 2016;67(4):427-433
\end{abstract}

Funding / Finansowanie: the research "Efficiency of lung ventilation and the body posture in people performing wind instruments" was conducted in the Medical University of Silesia (resolution No. KNW/2-046/10). Project manager: Anna Brzęk, Ph.D., P.T. 
Słowa kluczowe: czynniki ryzyka, spirometria natężona, zaburzenia wentylacji, instrument dęty, spirometria dynamiczna,

skutki medyczne

Corresponding author / Autorka do korespondencji: Anna Brzęk, Medical University of Silesia, School of Health Sciences,

Department of Kinesiology, Chair of Physiotherapy, Medyków 12, 40-754 Katowice, Poland

e-mail: aniabrzek@interia.pl

Received: November 13, 2015, accepted: March 9, 2016

\section{INTRODUCTION}

Learning to play a musical instrument requires several hours of daily practice. Music coming from wind instruments, i.e., a clarinet, saxophone, flute, tuba or French horn influences the audience in various ways. The body of a musician is otherwise affected.

Musicians performing wind instruments are particularly prone to the excessive respiratory efforts and a prolonged performance of wind instruments may lead to the respiratory muscles overload [1]. During the wind instrument performance the manner of breathing is slightly changed; lung tissue expansion, activity of respiratory muscles, the decrease in transpulmonary pressure is identical to physiologic. However, this phase is very short and the breath is taken "in rhythm" during the pause or at the end of the phrase. According to the Boyle, when the pressure is equalized, the expiratory phase begins with the tense inspiratory muscles $[2,3]$. Producing high pressures in mouth may lead to serious occlusal problems [4] and extreme, unnatural speeds of exhaled and inhaled air when repeated large number of times cause a considerable overload of the respiratory system. In consequence, lung tissue flexibility may be decreased and followed by, similarly in glass blowers, ventilation disorders of obstructive and restrictive type including, first of all, emphysema $[3,5,6]$.

Despite the number of scientific reports in this field, emphysema occurring in wind musicians once listed among professional diseases, introduced by The Regulation of the Council of Ministers of 2002 [7], was then revoked by the amendment in 2004 [8]. Emphysema is not on the list of Occupational Diseases, now. The current list of occupational diseases was enforced by the Council of Ministers on 30 June 2009 [9]. According to the Polish Society of Lung Diseases, the recommendation for spirometry is to assess the ability to perform particular professional activities as well as the evaluation of the professional risk $[10,11]$. Spirometry examination is a useful tool for a quick recognition of abnormalities in particular parameters calculated with regard to anthropometric data on the basis of the European Respiratory Society (ERS) standards [12].

The aim of the study has been the assessment of respiratory system efficiency for wind musicians in comparison with the control group. The following questions have been posed:

1. How do the parameters of dynamic spirometry change in the case of wind musicians?

2. On what factors do potential changes of spirometry parameters depend?

\section{MATERIAL AND METHODS}

Examinations covered a group of 31 musicians (group A) aged $14-24$ years old (mean (M) age: $17.12 \pm 2.96$ years old). Average time of playing wind instruments totaled 2.5-10 years $(\mathrm{M}=6.08 \pm 2.82$ years). Musicians dedicated 20-120 min per day to playing, 3-7 times per week (Table 1). All musicians performed their instruments in standing positions.

The control groups (group B) included 34 healthy young volunteers at similar age - ranging 14-24 years old $(\mathrm{M}=19.79 \pm 2.9$ years old $)$ not playing wind instruments. Initial characteristics of the examined group has been presented in the Table 2. Smoking habit, chronic diseases at the present time and in the past (e.g. allergic diseases, viral infection), cardiac diseases were exclusion criteria.

Conducted examinations were twofold. First, the spirometric test was performed with the use of a calibrated device Micro Lab Vaisys (Mikro Medical, Great Britain) in order to describe basic spirometric parameters. Obtained results were compared with the current ERS norms and related percentage rates were obtained. Such comparison allowed us to identify potential respiratory disturbances and their types.

Examination was performed in constant conditions in sitting on a chair position with lower limbs bent at $90^{\circ}$ angle, feet on the floor. Clothing of examinees did not constrict and their belts and/or ties were loosened. A mouthpiece joined with pneumotachometer 
Table 1. Characteristics of the examined groups

Tabela 1. Charakterystyka grup badanych

\begin{tabular}{|c|c|c|c|c|c|c|c|c|c|c|}
\hline \multirow{2}{*}{$\begin{array}{c}\text { Study group } \\
\text { Grupa } \\
\text { badana }\end{array}$} & \multicolumn{2}{|c|}{$\begin{array}{l}\text { Sex } \\
\text { Płeć } \\
{[\mathrm{n}]}\end{array}$} & \multicolumn{2}{|c|}{$\begin{array}{c}\text { Age } \\
\text { [years] } \\
\text { Wiek } \\
{[\text { w latach] }}\end{array}$} & \multicolumn{2}{|c|}{$\begin{array}{c}\text { Height } \\
\text { Wzrost } \\
{[\mathrm{cm}]}\end{array}$} & \multicolumn{2}{|c|}{$\begin{array}{l}\text { Weight } \\
\text { Waga } \\
{[\mathrm{kg}]}\end{array}$} & \multicolumn{2}{|c|}{$\begin{array}{c}\text { BMI } \\
{\left[\mathrm{kg} / \mathrm{m}^{2}\right]}\end{array}$} \\
\hline & $\begin{array}{l}\text { females } \\
\text { kobiety }\end{array}$ & $\begin{array}{c}\text { males } \\
\text { mężczyźni }\end{array}$ & $\mathrm{M} \pm \mathrm{SD}$ & $\begin{array}{l}\text { range } \\
\text { zakres }\end{array}$ & $\mathrm{M} \pm \mathrm{SD}$ & $\begin{array}{l}\text { range } \\
\text { zakres }\end{array}$ & $\mathrm{M} \pm \mathrm{SD}$ & $\begin{array}{l}\text { range } \\
\text { zakres }\end{array}$ & $\mathrm{M} \pm \mathrm{SD}$ & $\begin{array}{l}\text { range } \\
\text { zakres }\end{array}$ \\
\hline $\begin{array}{l}\text { A - musicians / } \\
\text { muzycy } \\
(\mathrm{N}=31)\end{array}$ & 18 & 13 & $17.12 \pm 2.96$ & $14.00-24.00$ & $169.41 \pm 8.32$ & $155.50-188.00$ & $56.22 \pm 8.44$ & $41.50-73.00$ & $19.49 \pm 1.95$ & $15.70-22.80$ \\
\hline $\begin{array}{l}\mathrm{B}-\text { control / } \\
\text { porównawcza } \\
(\mathrm{N}=34)\end{array}$ & 23 & 11 & $19.79 \pm 2.90$ & $14.00-24.00$ & $169.14 \pm 9.31$ & $158.00-189.00$ & $62.35 \pm 12.17$ & $46.00-95.00$ & $21.54 \pm 2.68$ & $16.60-29.60$ \\
\hline
\end{tabular}

BMI - body mass index / wskaźnik masy ciała, M - mean / średnia, SD - standard deviation / odchylenie standardowe.

Table 2. Frequency of playing wind instruments in the studied musicians (group A)

Tabela 2. Częstotliwość gry na instrumentach dętych wśród badanych muzyków (grupa A)

\begin{tabular}{|c|c|c|}
\hline $\begin{array}{l}\text { Variable } \\
\text { Zmienna }\end{array}$ & $\mathrm{M} \pm \mathrm{SD}$ & $\begin{array}{l}\text { Range } \\
\text { Zakres }\end{array}$ \\
\hline Age [years] / Wiek [w latach] & $17.12 \pm 2.96$ & $14.00-24.00$ \\
\hline \multicolumn{3}{|l|}{ Time of playing / Czas gry } \\
\hline per day / w ciągu dnia [min] & $73.54 \pm 43.43$ & $20.00-120.00$ \\
\hline per week / w ciągu tygodnia [min] & $350.70 \pm 221.76$ & $72.00-672.00$ \\
\hline per year [h] / w ciągu roku [godz.] & $438.38 \pm 277.21$ & $90.00-840.00$ \\
\hline
\end{tabular}

Abbreviations as in Table 1 / Skróty jak w tabeli 1.
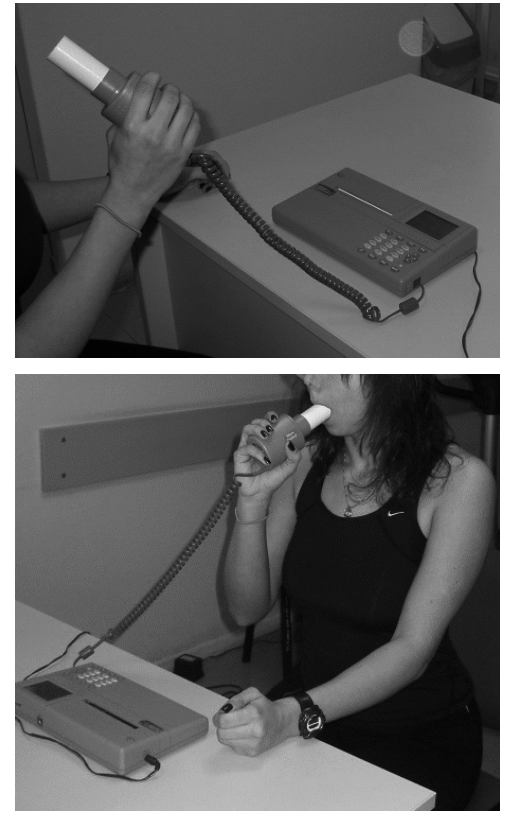

Photo 1. Position of the examined person for spirometry

Fot. 1. Pozycja badanego podczas spirometrii was tightly inserted in a subject's mouth and a clamping clip was set on their noses (Photo 1).

The examinee was well informed about examination procedure and encouraged during performing it. Using the previously described criteria, an adequate test requires a minimum of three acceptable forced vital capacity (FVC) maneuvers. Acceptable repeatability is achieved when the difference between the largest and the next largest FVC is $0.15 \mathrm{l}$ and the difference between the largest and next largest forced expiratory volume in $1 \mathrm{~s}\left(\mathrm{FEV}_{1}\right)$ is 0.151 [13]. The spirometry parameters were used for statistical analysis: expiratory vital capacity (EVC), FEV, FVC, peak expiratory flow (PEF), and $\mathrm{FEV}_{1} / \mathrm{FVC}$ (pseudo-Tiffenau index).

Next, chest circumference on Th12 height and xiphoid process and stomach circumference in tuck sit position were measured with a centimeter tape. Measurements were taken during slow inhalation and maximal exhalation so that the respiratory track could be indirectly described. 
People with diagnosed scoliosis were excluded from the examination (spinal curvature exceeded 10) so that spirometry results were not distorted [14].

Additionally, a survey was conducted comprising 14 questions in order to describe a type of instrument, its weight, playing time and frequency. Spirometry results relating to sex were evaluated first. Then, results were compared in order to indicate relations between them. Excel and Statistica v. 10 programmes were used. To describe a normal distribution SmirnowKołmogorow test was used. To indicate significance of differences between groups with normal distribution, the Student's t-test was used for dependent and independent attempts. Relationships between parameters were verified with the Pearson $r$ correlation and for non-parameters characteristics test $\mathrm{Chi}^{2}$ was used. As statistically significant level $\mathrm{p}<0.05$ was adopted.

The Bioethical Commission of the Medical University of Silesia expressed its consent to perform the tests. The research was conducted in the Medical University of Silesia in Katowice (Poland), the resolution No. KNW/2-046/10. The presented results are a part of a larger science project and the consent was obtained from the Bioethical Commission of the Medical University of Silesia in Katowice (Poland), the resolution No. KNW/0022/KB1/162/10.

\section{RESULTS}

The spirometry examination analysis revealed differences in individual results. Characteristics of a normal distribution were presented in the results. The Table 3 presents analyzed spirometry parameters in both groups and significance of the differences between them.
As it has been shown, respiratory parameters were within the range of physiological norms and $\mathrm{FEV}_{1} / \mathrm{FVC}$ exceeded in both groups the values of $100 \%$. Surprisingly, the FVC and EVC values, despite being included in physiological norms, were significantly lower in the group of musicians than in the control group (Figure 1). If the values of $\mathrm{FEV}_{1}$ and PEF inform about resistances in respiratory tracts, they may provide indirect evidence of respiratory muscles force [15].

The obtained upper values of the parameters in the group of musicians may prove that a proper stomach breathing (diaphragmatic breathing) plays a considerable role in acquiring performing wind instrument technique [16].

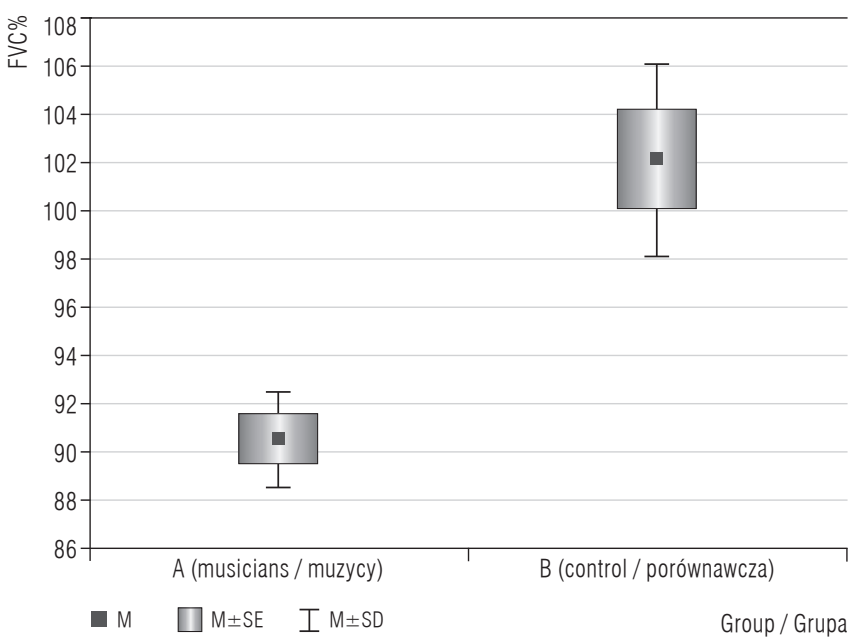

SE - standard error / błąd standardowy.

Other abbreviations as in Table 1 / Inne skróty jak w tabeli 1.

Fig. 1. Forced vital capacity $(\mathrm{FVC} \%)$ in the examined groups Ryc. 1. Natężona pojemność życiowa (FVC\%) w grupach badanych

Table 3. Spirometry parameters in the examined groups and significance of the difference between them Tabela 3. Parametry spirometryczne w badanych grupach i istotność statystyczna różnic między nimi

\begin{tabular}{|c|c|c|c|c|c|}
\hline \multirow{2}{*}{$\begin{array}{l}\text { Parameter } \\
\text { Parametr }\end{array}$} & \multicolumn{2}{|c|}{$\begin{array}{l}\text { Group A (musicians) } \\
\text { Grupa A (muzycy) }\end{array}$} & \multicolumn{2}{|c|}{$\begin{array}{c}\text { Group B (control) } \\
\text { Grupa B (porównawcza) }\end{array}$} & \multirow{2}{*}{$\mathrm{p}$} \\
\hline & $\mathrm{M} \pm \mathrm{SD}$ & $\begin{array}{l}\text { range } \\
\text { zakres }\end{array}$ & $\mathrm{M} \pm \mathrm{SD}$ & $\begin{array}{l}\text { range } \\
\text { zakres }\end{array}$ & \\
\hline $\mathrm{EVC} \%$ & $88,16 \pm 6,87$ & $77-105$ & $99,26 \pm 12,33$ & $75-120$ & $<0.0001$ \\
\hline FVC\% & $90,54 \pm 5,62$ & $78-103$ & $102,07 \pm 11,97$ & $79-131$ & $<0.001$ \\
\hline $\mathrm{FEV}_{1} \%$ & $103,54 \pm 12,54$ & $72-125$ & $95,81 \pm 16,64$ & $79-131$ & $<0.03$ \\
\hline $\mathrm{PEF} \%$ & $89,54 \pm 13,01$ & $65-114$ & $79,61 \pm 14,02$ & $51-102$ & $<0.004$ \\
\hline $\mathrm{FEV}_{1} / \mathrm{FVC} \%$ & $108,03 \pm 8,38$ & $82-118$ & $100,07 \pm 10,35$ & $70-118$ & $<0.001$ \\
\hline
\end{tabular}

EVC - expiratory vital capacity / wydechowa pojemność życiowa, FVC - forced vital capacity / natężona pojemność życiowa, FEV - forced expiratory volume in $1 \mathrm{~s} /$ natężona objętość wydechowa pierwszosekundowa, PEF - peak expiratory flow / szczytowy przepływ wydechowy, FEV/FVC\% - pseudo-Tiffeneau index / wskaźnik pseudo-Tiffeneau. Other abbreviations as in Table 1 / Inne skróty jak w tabeli 1. 

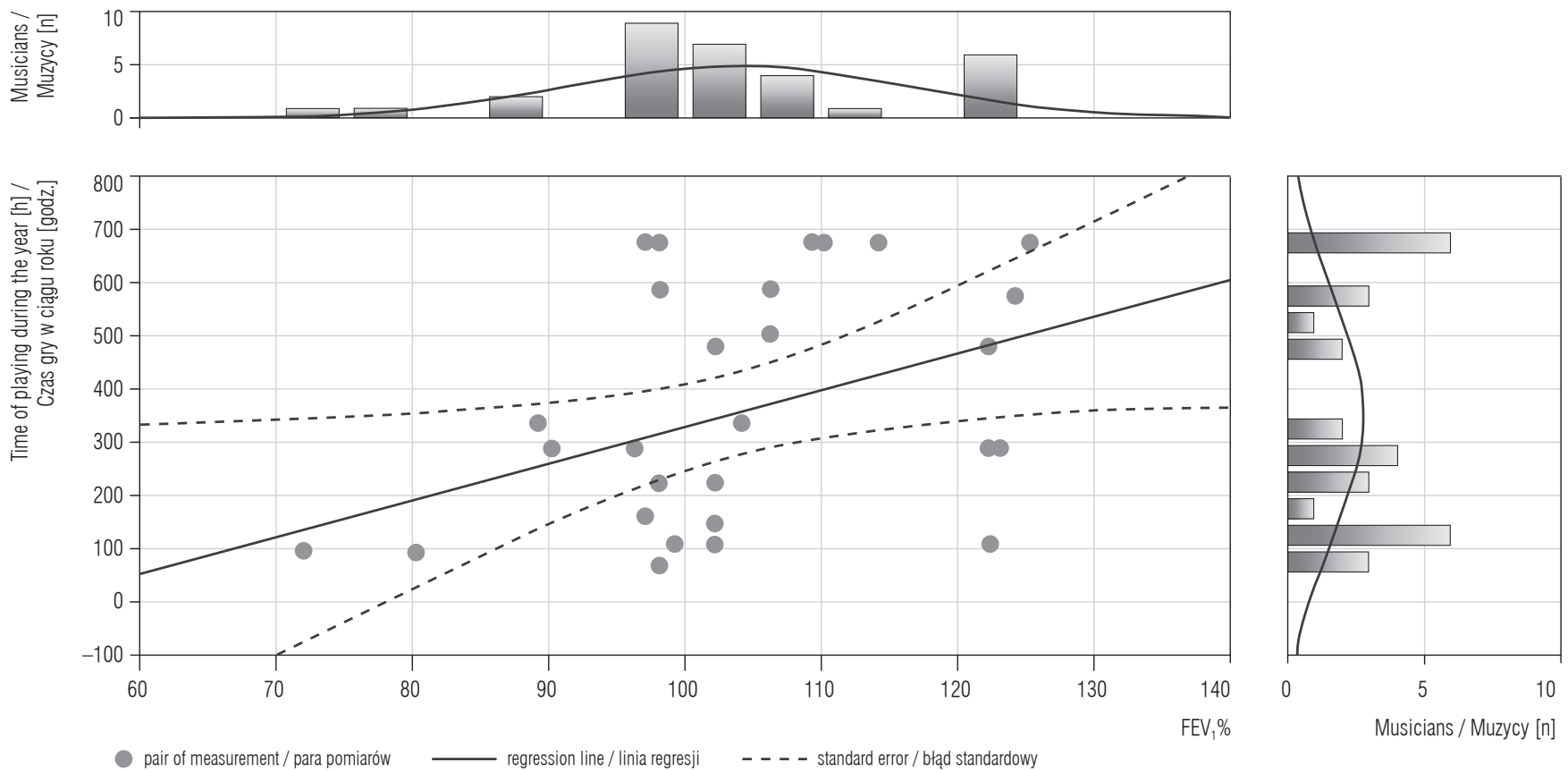

* Correlation coefficient $=0.38903$ / Współczynnik korelacji $=0,38903$

Fig. 2. Correlation between forced expiratory volume in $1 \mathrm{~s}\left(\mathrm{FEV}_{1} \%\right)$ and a number of hours of playing wind instrument by the studied musicians $(\mathrm{N}=31)$ during one year (group $\mathrm{A})^{*}$

Ryc. 2. Zależność między natężoną objętością wydechową pierwszosekundową ( $\left.\mathrm{FEV}_{1} \%\right)$ a liczbą godzin gry na instrumentach dętych przez badanych muzyków $(\mathrm{N}=31) \mathrm{w}$ ciągu roku (grupa $\mathrm{A})^{*}$

It may also be seen that height and weight of the body did not influence the spirometric parameters. The pseudo-Tiffenau index depended in both groups on age - line dependence (both $\mathrm{r}$ in the range of $0.34-0.59, \mathrm{p}<0.04$ ). Time of performing wind instruments influenced different parameters of forced expiratory spirometry ( $\mathrm{r}$ in the range of $0.37-0.65 ; \mathrm{p}<0.03$ ) (Figure 2).

Statistical analyses reveal that in a group of musicians $45 \%$ of examinees used diaphragmatic breathing - observed especially in men, in $31 \%$ of examinees mixed respiratory tract was observed - particularly among women and in the remaining $24 \%$ - chest respiratory tract was observed - equally in men and women. However, in the control group chest respiratory tract was predominant $(78.7 \%)$. Only in individual cases did values of spirometric parameters exceed the relevant ranges. Therefore, the relationship between them and respiratory tract was not noted. In the main group, in $42 \%$ of examinees a tendency towards the increase of $\mathrm{FEV}_{1} \%$ values by $8.5 \%$ on average above normal standards, according to the ERS in musicians with diaphragmatic breathing, was noted. In the control group increased values of more than $5.8 \%$ were obtained by $60 \%$ of those who breathed by chest respiratory tract. In the group of musicians no value equal to
pseudo-Tiffenau index which, according to the American Thoracic Society (ATS) [12] is used to identify obstructive changes, was obtained. In the control group, in the case of one man changes in $\mathrm{FEV}_{1} \%$ value equal to $71 \%$ were observed.

To summarize, spirometry parameters in accordance with standards may be the evidence of a good condition of the respiratory system and a lack of lung ventilation disturbances, which may result from the fact of making constantly repeated efforts by the respiratory system or/and conducted education on a proper breathing during wind instrument performance or a very short period of time of playing an instrument for 2.5-10 years $(\mathrm{M}=6.08 \pm 2.82$ years). However, even such a short time causes the statistically significant increase of the majority of dynamic spirometry parameters.

\section{DISCUSSION}

Incipient lung diseases cause mechanic changes in lung tissue. However, because of a lack of observed symptoms, they are difficult to detect with a physical or radiological examination [17]. Particularly people who constantly, during a long period of time perform the same activities connected with respiratory effort are 
at risk. This group includes wind musicians and glass blowers. The decrease in vital capacity (VC) accompanied by the correct or slightly increased Tiffeneau indications (above 85-90\%) and maximum expiration flows may suggest restrictive changes. Only appropriate verification based on total lung capacity (TLC) of these factors which are not measured in spirometry allow to diagnose or exclude a disease [6]. Having said that, the question arises as to whether it is appropriate to qualify examinees as "healthy" until it is accurately verified.

According to data presented by the ERS $[6,12]$ and the data presented by Hankinson [18] for screening examination, values of $\mathrm{FEV}_{1} / \mathrm{FVC}$ are irrespective of height but dependent only on age - which has been confirmed in our examinations. So there is an incoherence, because according to recommendations of the Polish Society of Lung Disease, height measurement of an examined person is necessary and in the case of lower limb amputation or significant spinal abnormality arms-spread width is measured [19].

In foreign reports $[1,2,20,21]$ but also in the Polish ones [22], full, deep and quick inhalation is emphasized in performing wind instrument without focus on one respiratory tract. As it is explained by Hajda in his clarinet method [23, p. 4] respiration should be even and slow. It is recommended to combine stomach and ribs breathing based on diaphragm. It enables, which is further written, possibly deep respiration. It may be an explanation of the fact that in a group of wind musicians in 10 examinees ( 9 women and 1 man) combined respiratory tract was adopted. All the examinees confirmed that they have learnt or they are learning an appropriate manner of breathing involving not only diaphragm but also chest. Unfortunately, according to Rożek-Mróz [3], long lasting forced tense in respiratory tracts may affect respiratory system and in consequence, it may lead to emphysema which has been proven by the high value of $\mathrm{PEF} \%$ and $\mathrm{FEV}_{1} \%$ in our examinations (Table 1). Having said that, some practical recommendations may be given. It seems reasonable for wind instrument musicians to undergo frequent prophylactic examinations - spirometry measurements as primary prevention of lung ventilation disturbances aimed at prompt detection of potential lung disorders.

\section{CONCLUSIONS}

1. Performing wind instruments does not cause lung ventilation disturbances and spirometric parameters in accordance with norms may be the evidence of a good respiratory system efficiency.
2. The change in some dynamic spirometry parameters may depend on a period of time of performing wind instrument.

3. Forced expiratory volume in $1 \mathrm{~s}\left(\mathrm{FEV}_{1}\right)$ and peak expiratory flow (PEF) may be the evidence of getting an appropriate respiratory technique.

\section{REFERENCES}

1. Fuhrmann AG, Franklin PJ, Hall GL. Prolonged use of wind or brass instruments does not alter lung function in musicians. Respir Med. 2011;105:761-7, http://dx.doi. org/10.1016/j.rmed.2011.01.017.

2. Frederiksen B. Arnold Jacobs: Song and wind. 6th ed. Illinois: WindSong Press Ltd.; 2006. p. 99-109.

3. Zuskin E, Mustajbegowic J, Schachter EN, Kern J, Vitale K, Pucarin-Cvetkovic J, et.al. Respiratory function in wind instrument players. Med Lav. 2009;100(2):133-41.

4. Zadurska M, Siemińska-Piekarczyk B, Fidecki M, Jakubowska M, Jalowski S, Jaśkowski J, et al. [Evaluation of malocclusion in wind instruments players]. Czas Stomat. 2006;LIX(2):126-32. Polish.

5. Zuskin E, Butkovic D, Schachter N, Mustajbegovic J. Respiratory function in workers employed in the glassblowing industry. Am J Ind Med. 1993;23(6):835-44, http://dx.doi.org/10.1002/ajim.4700230602.

6. Sagdeo MM, Khuje PD. Pulmonary functions in trained and untrained wind instrument blowers. People's J Sci Res. 2012;5(2):9-12.

7. Marek K. [Principles of work capacity assessment in occupational respiratory diseases]. Med Pr. 2002;53(3): 245-52. Polish.

8. Marek K. [An amendment of the schedule of occupational diseases]. Bezpiecz Pr Nauka Prakt. 2004;4:16-8. Polish.

9. [Regulation of the Council of Ministers of 30 June 2009 on the list of occupational diseases. J Laws 2009, No 105, item 869]. Polish.

10. Franczuk M, Antczak A. [Indications and contraindications for performing spirometry]. Pneumonol Alergol Pol. 2004;72:13-6. Polish.

11. Jasik A, Marcinowska-Suchowierska E. [Spirometry in general practice]. Postepy Nauk Med. 2007;4:125-9. Polish.

12. American Thoracic Society/European Respiratory Society. ATS/ERS steatement on respiratory muscle testing. Am J Respir Crit Care Med. 2002;166:518-624, http:// dx.doi.org/10.1164/rccm.166.4.518.

13. Miller MR, Hankinson J, Brusasco V, Burgos F, Casaburi R, Coates A, et al. Standardisation of spirometry. 
Eur Respir J. 2005;26:319-38, http://dx.doi.org/10.1183/ 09031936.05.00034805.

14. Gnat R, Saulicz E, Ryngier P, Zięba M. [The value of selected spirometric parameters in children and adolescents with scoliosis of the first and second degree]. Fizjoterapia. 2001;9(1):13-9. Polish.

15. Górski J. [Physiological basis of physical activity]. Warszawa: PZWL; 2006. p. 235-65. Polish.

16. Wolfe J, Garnier M, Smith J. Vocal tract resonances in speech, singing, and playing musical instrument. HFSP Journal. 2009;3(1):6-23.

17. Khuje PD, Hulke SM. Dynamic lung volumes and capacities in marriage band party musicians. Int J Biol Med Res. 2011;2(3):747-9.

18. Hankinson JL, Crapo RO, Jensen RL. Spirometric reference values for the 6-s FVC maneuver. Chest. 2003;124: 1805-11, http://dx.doi.org/10.1378/chest.124.5.1805.
19. Gondorowicz K, Siergiejko Z. [Performance of studies procedures, acceptability and repeatability of measurements]. Pneumonol Alergol Pol. 2004;72:16-8. Polish.

20. Dhule SS, Sunita BN, Gawali SR. Pulmonary function tests in wind instrument players. Int J Sci Res. 2013;2(5):384-6.

21. Kahane JC, Beckford NS, Chorna LB, Teachey JC, McClelland DK. Videofluoroscopic and laryngoscopic evaluation of the upper airway and larynx of professional bassoon players. J Voice. 2006;20(2):297-307, http:// dx.doi.org/10.1016/j.jvoice.2005.03.003.

22. Pniak J. [Little school of tuba]. Kraków: Polskie Wydawnictwo Muzyczne; 2005. Polish.

23. Hejda T. [School for clarinet]. Kraków: Polskie Wydawnictwo Muzyczne; 2013. Polish.

This work is available in Open Access model and licensed under a Creative Commons Attribution-NonCommercial 3.0 Poland License / Ten utwór jest dostępny w modelu open access na licencji Creative Commons Uznanie autorstwa - Użycie niekomercyjne 3.0 Polska - http://creativecommons.org/ licenses/by-nc/3.0/pl/deed.en. 